\title{
Identification of novel small molecule Beclin 1 mimetics activating autophagy
}

\author{
Jia Yu ${ }^{1,2, *}$, Lan Lan ${ }^{2, *}$, Seth J. Lewin ${ }^{2}$, Steven A. Rogers ${ }^{3}$, Anuradha Roy ${ }^{4}$, Xiaoqing \\ $\mathbf{W u}^{2}$, Philip Gao ${ }^{5}$, John Karanicolas ${ }^{2,6}$, Jeffrey Aubé ${ }^{3,7}$, Baiwang Sun ${ }^{1}$ and Liang $\mathbf{X u}^{2}$ \\ ${ }^{1}$ School of Chemistry and Chemical Engineering, Southeast University, Nanjing 210089, China \\ ${ }^{2}$ Department of Molecular Biosciences, The University of Kansas, Lawrence, Kansas 66045, USA \\ ${ }^{3}$ Center of Biomedical Research Excellence, The University of Kansas, Lawrence, Kansas 66045, USA \\ ${ }^{4}$ High Throughput Screening Laboratory, The University of Kansas, Lawrence, Kansas 66045, USA \\ ${ }^{5}$ COBRE-PSF Protein Production Group, The University of Kansas, Lawrence, Kansas 66045, USA \\ ${ }^{6}$ Center for Bioinformatics, The University of Kansas, Lawrence, Kansas 66045, USA \\ ${ }^{7}$ Department of Medicinal Chemistry, The University of Kansas, Lawrence, Kansas 66045, USA \\ *These authors contributed equally to this work
}

Correspondence to: Liang Xu, email: xul@ku.edu

Baiwang Sun, email: chmsunbw@seu.edu.cn

Keywords: Beclin 1 mimetics, autophagy, Bcl-xL protein, cancer, high-throughput screen

Received: March 26, 2017 Accepted: May 06, $2017 \quad$ Published: May 18, 2017

Copyright: Yu et al. This is an open-access article distributed under the terms of the Creative Commons Attribution License 3.0 (CC BY 3.0 ), which permits unrestricted use, distribution, and reproduction in any medium, provided the original author and source are credited.

\section{ABSTRACT}

Anti-apoptotic proteins $\mathrm{Bcl}-2$ and $\mathrm{Bcl}-\mathrm{xL}$ could block autophagy by binding to Beclin 1 protein, an essential inducer of autophagy. Compounds mimicking Beclin 1 might be able to disrupt $\mathrm{Bcl}-\mathrm{xL} / 2$-Beclin 1 interaction, free out Beclin 1, and thus trigger autophagy. In order to identify small molecule Beclin 1 mimetics, a fluorescence polarization-based high-throughput screening of 50,316 compounds was carried out with a $Z^{\prime}$ score of $0.82 \pm 0.05$, and an outcome of 58 hits. After the structure analysis, three acridine analogues were unveiled and confirmed using the fluorescence polarization assay and the surface plasmon resonance assay. Moreover, a set of 17 additional acridine analogues was prepared and tested. Compound 7 showed selectivity for $\mathrm{Bcl}-\mathrm{xL}\left(K_{D}=6.5 \mu \mathrm{M}\right)$ over Bcl-2 $\left(K_{D}=160 \mu \mathrm{M}\right)$ protein, and potent cytotoxicity (nanomolar scale) in PC-3, PC-3a and DU145 prostate cancer cells. Furthermore, induction of autophagy was also demonstrated in PC-3 and PC-3a cells treated with some acridine compounds by LC3 conversion immunoblotting and LC3 fluorescence microscopy. These Beclin 1 mimetics will be invaluable tools for developing novel autophagy inducers, better understanding the roles of autophagy in cancer, and will contribute to cancer therapy.

\section{INTRODUCTION}

Autophagy is an essential, evolutionarily conserved process that degrades protein aggregates and damaged organelles in order to maintain cytoplasmic homeostasis [1]. It begins with the sequestration of cytoplasmic constituents in double-membrane vesicles, called autophagosomes. The vesicles then fuse with lysosomes to form autolysosomes, where the engulfed contents undergo degradation and recycling to sustain cellular metabolism [2].
In normal cells, autophagy is generally considered as a cytoprotective mechanism [1]. However, the roles of autophagy in cancer cells are paradoxical and controversial. Autophagy acts both as a tumor suppressor that prevents tumor initiation and as a protector of cancer cell survival that removes damaged organelles under stress conditions [3, 4]. The outcome of autophagy regulation in cancer cells may vary depending on the types of cancers, individual characteristics of cancer cells, microenvironments, and therapeutic treatments $[5,6]$. 
Under certain circumstances, overactivation of autophagy can lead to autophagic cell death, or type II programmed cell death $[6,7]$. In addition, most of the cellular systems where autophagy has been proven to contribute to cell death are defect in the apoptosis signaling pathways, as is the case in most tumors [8,9]. Therefore, even though autophagy is most likely a pro-survival response in normal cell homeostasis, it might be a backup death program in apoptosis-resistant tumor cells $[7,9,10]$. If this hypothesis is correct, drugs that specifically trigger autophagic cell death should be well-tolerated due to highly specific killing of cancer cells. Moreover, autophagic cell death is a tempting way to circumvent apoptosis-resistance [11-13].

Autophagy is regulated by a set of conserved proteins, the autophagy-related (Atg) proteins [14]. Beclin 1, also named Atg6, is the first identified mammalian Atg protein and an essential autophagy inducer [15]. Beclin 1 forms a regulatory complex with class III phosphatidylinositol-3-kinase (class III PI3K or VPS34) that is important in the initiation of autophagy [16]. Beclin 1 is also a haploinsufficient tumor suppressor and mono-allelic deleted in $40 \%-75 \%$ human breast, ovarian and prostate cancer [15, 17]. Bcl-2 (B cell lymphoma 2) family proteins have been proposed as dual regulators of apoptosis and autophagy [18]. The anti-apoptotic Bcl-2 homologs, Bcl-2 and Bcl-xL, can downregulate autophagy by interacting with the Beclin 1/class III PI3K complex, and sequestering Beclin 1 [16, 19, 20]. Beclin 1 carries one Bcl-2-homology-3 (BH3) domain, which is important for the Bcl-2-Beclin 1 interaction and required for Bcl-2mediated inhibition of autophagy [21,22].

Several Bcl-2 inhibitors have been proven to competitively disrupt the interaction between Beclin 1 and $\mathrm{Bcl}-2 / \mathrm{xL}$, and induce autophagy. (-)-Gossypol is the first Bcl-2 inhibitor approved by FDA for clinical testing (AT-101) and has entered Phase II-IIb clinical trials (www.ClinicalTrials.gov). In our previous studies, we demonstrate that (-)-gossypol preferentially induces autophagy in androgen-independent or castration-resistant prostate cancer cells that have high levels of Bcl-2 and are resistant to apoptosis, whereas apoptosis is preferentially induced in androgen-dependent cells with low Bcl-2 [8]. (-)-Gossypol induces autophagy via blocking Bcl2-Beclin 1 interaction at the endoplasmic reticulum [8]. Moreover, the Bcl-2 inhibitor ABT-737 induces high levels of autophagy via binding to the $\mathrm{BH} 3$ binding groove of Bcl-2 or Bcl-xL (but not Mcl-1) and freeing out Beclin 1 [23-25]. ABT-737-induced autophagy cannot be inhibited by $\mathrm{Bcl}-2$ or $\mathrm{Bcl}-\mathrm{xL}$ overexpression, yet it is abolished by transfection with Mcl-1 or by the siRNA mediated knockdown of Beclin 1 [23, 26]. ABT-737 and its analogue ABT-263 (navitoclax) are in phase I/ phase II clinical trials [27].

In our previous screen for inhibitors of Bcl-2, we have discovered and synthesized a series of small molecule BH3-mimetics, including (-)-gossypol $[8,28]$. We hypothesize that, in our original screening, we only focused on inhibitors of $\mathrm{Bcl}-2-\mathrm{Bax} / \mathrm{Bak}$ interaction that induce apoptosis, thus we may have missed some potential hits that more potently inhibit Bcl-2/xL-Beclin 1 interaction and induce autophagy instead of apoptosis. Here we report the discovery of several acridine compounds as small molecule Beclin 1 mimetics using the fluorescence polarizationbased (FP-based) high-throughput screening (HTS), the surface plasmon resonance (SPR) assay, and cell-based biological activity assays. The acridine compounds have inhibitory effects on the proliferation of prostate cancer cells and induce autophagy. These Beclin 1 mimetics represent promising leads to develop novel molecular therapy for human cancer with Bcl-2/xL overexpression and resistant to conventional chemo/radiotherapy.

\section{RESULTS}

\section{FP-based HTS for Beclin 1 mimetics}

To discover small molecule inhibitors of Bcl-xLBeclin 1 interaction, a sensitive, quantitative, in vitro FP-based binding assay was established and optimized for HTS. We first determined the proper Beclin 1 peptide for the $\mathrm{FP}$ assay. $\mathrm{BH} 3$ domain is necessary and sufficient for the interaction between Beclin 1 and Bcl-xL [22]. We therefore designed five fluorescein-labeled Beclin 1-BH3 peptides with different length. They all contain the critical residues for the binding behavior (Figure 1A). A 16-mer (a 16 amino acid long peptide) Bak-BH3 peptide was used as a positive control [29]. As shown in Figure 1B, Bcl$\mathrm{xL}$ was titrated to a fixed solution of $50 \mathrm{nM}$ fluorescent peptide and the changes of FP values were calculated. 20-mer Beclin peptide, 26-mer Beclin peptide as well as Bak peptide exhibited good binding curves to $\mathrm{Bcl}-\mathrm{xL}$ in this assay, while peptides of shorter sequence (e.g. 8-mer, 10-mer and 12-mer) showed low or no binding affinity. Thus, we chose 20 -mer, the shorter one of the two active peptides, as the binding peptide in the following FP assay. Buffer condition was then optimized (data not shown). Finally, 20-mer and Bak peptide was demonstrated to bind to $\mathrm{Bcl}-\mathrm{xL}$ protein with equilibrium dissociation constants $\left(K_{\mathrm{d}}\right)$ of $969.5 \mathrm{nM}$ and $33.92 \mathrm{nM}$, respectively (Figure 1B), which are sufficient for the following FP-based assays. Then, we set up a FP-based competitive binding inhibition experiment using $50 \mathrm{nM}$ of fluorescent 20 -mer and $2 \mu \mathrm{M}$ of Bcl-xL (Figure 1C). Positive compounds, ABT-263 $[30,31]$ and (-)-gossypol [12] are capable of freeing out fluorescent $20 \mathrm{mer}$ to experimental solution, and ABT263 is more potent than (-)-gossypol (Figure 1C). These results demonstrated that this FP competitive binding assay is suitable for identify small molecule inhibitors that can mimic Beclin 1 and abrogate Bcl-xL-Beclin 1 interaction.

Next, we optimized the FP competitive binding assay in a 384-well microplate format and carried out a 
small-scale HTS using a small library, which contains 6580 compounds from Prestwick, Microsource and our in-house CMLD library. Then, the FP assay was optimized and applied in screening the larger Chembridge library consisting of 43736 compounds. The scattergrams of inhibitors activity are shown in Figure 1D-1E. HTS cascades are shown in Supplementary Figure 1A1B. According to the percent of inhibition, 68 active compounds $(>$ median $+3 \mathrm{SD})$ were selected as initial hits. After removal of autofluorescent and repeated compounds, 41 hit compounds from the first screen (A01-A41) and 17 hit compounds from the second screen (B01-B17) were chose for further studying, giving an overall hit rate of $0.12 \%$ (Supplementary Table 1 ). The average $Z^{\prime}$ value was $0.82 \pm 0.05$ with a signal to background window of 1.4 , indicating a robust and reliable HTS assay (Figure 1D-1E; Supplementary Figure 1C-1F). A complete list of the screening hits and the confirmatory data were listed in Supplementary Table 2-3 with PubChem Chemical ID (CID) number. All chemical structures can be found on the PubChem website (http://pubchem.ncbi.nlm.nih.gov/).

\section{Structural similarity analysis of HTS hits}

We employed a chemical structure clustering tool, a free online service from PubChem, to access the structure similarity of our hits. Tanimoto coefficient was used to quantify the structure similarity, which is by far the most popular and in widespread use today in computational medicinal chemistry [32]. Structural similarity clustering of 58 hits by a Tanimoto distance of 0.3 resulted in 29 different clusters and singletons. Three major clusters were revealed (Figure 2). We found that some compounds in cluster I might be promiscuous, assay-duping molecules. They have the common structure of polyhydroxy naphthalene or anthraquinone, therefore can be considered as pan-assay interference compounds, or PAINS [33]. After carefully looking over the hit structures, three acridine analogues, A13, A15 and A21, from cluster II and cluster III were subjected to further analysis (Figure 2).

\section{Validation of acridine compounds using two biochemical assays}

We first validated the abilities of three acridine analogues to disrupt Bcl-xL-20-mer complex using the FP assay. As shown in Figure 3A, all three compounds exhibited potent and dose-dependent inhibitory effects in this assay $\left(\mathrm{A} 13, K_{\mathrm{i}}=0.84 \mu \mathrm{M} ; \mathrm{A} 15, K_{\mathrm{i}}=28.04 \mu \mathrm{M}\right.$; A21, $\left.K_{\mathrm{i}}=13.15 \mu \mathrm{M}\right)$.

Next, we developed a surface plasmon resonance assay to validate the binding activities of these compounds. SPR is a label-free, non-fluorescent biochemical assay that could assess the binding behavior directly. Bcl-xL protein was immobilized to the sensor surface, and analytes in solution were injected over the surface. As shown in Figure
3B, compounds A13, A15, and A21 could bind to Bcl-xL at the concentration of $10 \mu \mathrm{M}$, and the SPR sensorgram displayed direct interactions between compounds and Bcl$\mathrm{xL}$ protein. For example, while A21 was injected over the surface, response unit (RU) increased rapidly, indicating a fast accumulation or binding of A21 on the surface; while A21 was diluted away by running buffer, RU decreased rapidly, indicating a fast dissociation of the complex. Obviously, A21 dissociated faster than the other two acridine compounds, indicating the different interactions between Bcl-xL and the acridine compounds (Figure 3B). Taken together, FP and SPR results confirmed that compounds A13, A15, and A21 could abrogate Bcl-xL-Beclin 1 interaction through direct binding to $\mathrm{Bcl}-\mathrm{xL}$ protein.

\section{Acridine compounds inhibit cell growth and induce autophagy in human prostate cancer cells}

Three acridine analogues, A13, A15, and A21, were further assessed in cell-based assays. They exhibited potent inhibitory effects on the growth of human prostate cancer cell lines PC-3, PC-3a and DU145 (Table 1; Figure 4A), which have high levels of Bcl-2 family proteins. Moreover, A15 and A21 exhibited higher cytotoxicity in PC-3 and PC-3a than in DU145 cells, while A13 showed similar cytotoxicity to all three types.

Next, we tested LC3 conversion by the immunoblotting in $\mathrm{PC}-3$ and $\mathrm{PC}-3 \mathrm{a}$ prostate cancer cells. Conversion of LC3-I to LC3-II is widely accepted as a marker of autophagy [34]. Increased level of LC3II was observed in cells treated with A13, A15 or A21, demonstrating their abilities to induce autophagy (Figure 5A). Using a tandem fluorescent-tagged LC3, we monitored the autophagic flux levels in PC-3 and PC-3a cells. Because GFP (green fluorescent protein) signal is quenched at the low $\mathrm{pH}$ inside the lysosomes, while RFP (red fluorescent protein) is stable at low pH condition [35], this assay could detect autophagosomes (yellow puncta) and autolysosomes (red puncta) at the same time. As shown in Figure 5B, we observed many strong red puncta in PC3a and PC-3 cells transfected with RFP-GFP-LC3 and treated with compounds A13, A15, or A21 for $24 \mathrm{~h}$. This result demonstrated the appearance of autolysosomes and the activation of autophagic flow in the cells. Based on the results of two cellular assays, we established the activation of autophagic process in PC-3 and PC-3a treated with compound A13, A15 or A21. These results are consistent with our design strategy that the compounds disrupting Bcl$\mathrm{xL}-$ Beclin 1 interaction could induce autophagy.

\section{Structure-activity relationship (SAR) analysis of A21 derivatives}

To test the activity of acridine structure and gain a primary SAR, we built a set of seventeen A21 analogues. According to their structures, these compounds were 
divided into four groups (Figure 6A). Group I (1, 2, 4 and 5 ) includes compounds with only one substitution at 9 position of the acridine ring; group II (7-10 and 13-17) contains 6-chloro-2-methoxyacridines with different substitutions at 9 position; group III (11 and 12) consists of 2-methoxyacridines with different substitutions at 9 position; and the acridine rings of compounds in group IV (3 and 6) were replaced by other heterocycles.

The binding affinity of these acridine analogues to Bcl-xL protein was determined using the SPR assay. Figure $6 \mathrm{~B}$ showed that only compound 7 had higher binding level than original hit A21 at the concentration

A

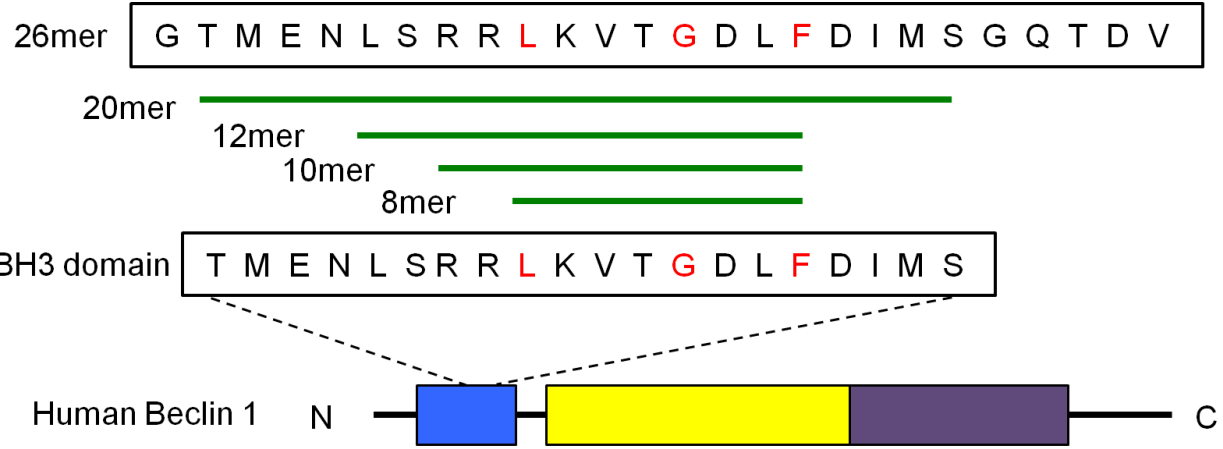

Bcl-2 binding domain $\square$ coiled-coil domain (CCD) $\square$ Evolutionarily conserved domain (EDC)

B

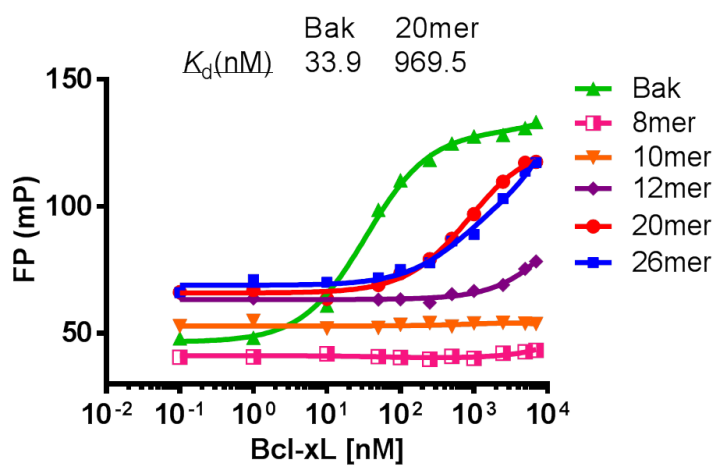

D

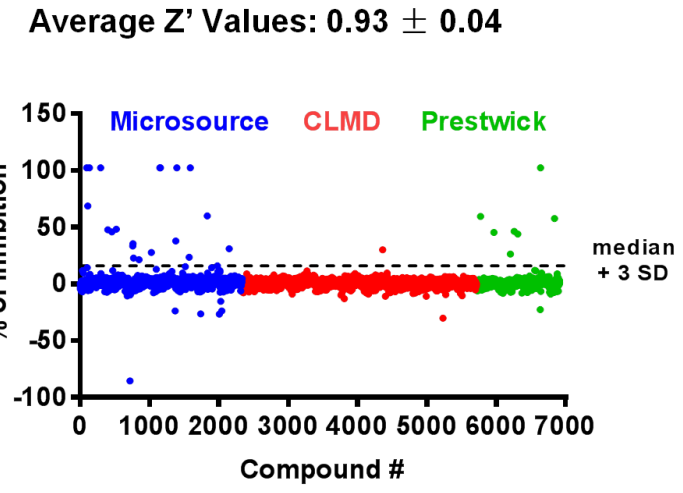

C

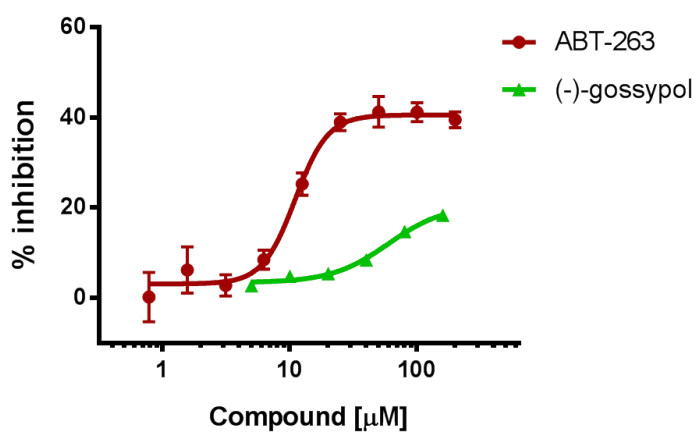

$\mathrm{E}$

Average Z' Values: $\mathbf{0 . 7 0} \pm \mathbf{0 . 0 5}$

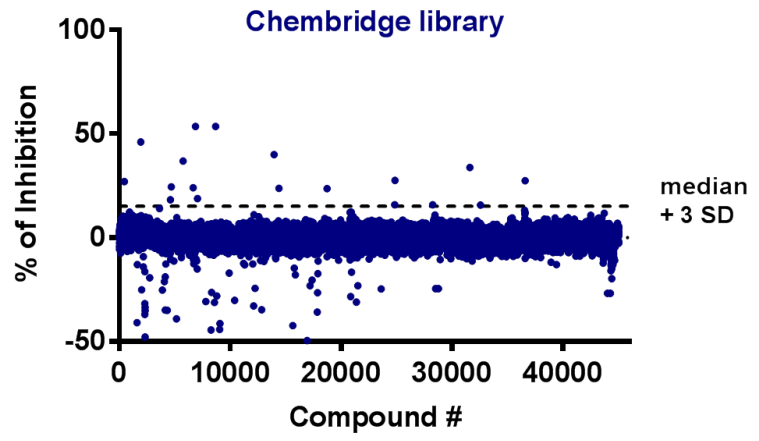

Figure 1: FP-based HTS for Beclin 1 mimetics. (A) Schematic presentation of the Beclin 1 protein and sequences of five synthetic peptides modified from Beclin 1 BH3 peptide. Diagram of human Beclin 1 protein with different domains is shown in the bottom. BH3 domain is necessary and sufficient for interaction with Bcl-2/Bcl-xL. Amino acids in red are the critical residues for the binding. (B) Five fluorescein-labeled Beclin $1 \mathrm{BH} 3$ peptides were tested for their binding ability to Bcl-xL protein in FP assay. Fluorescein-labeled Bak BH3 peptide was used as a positive control. Bcl-xL protein was titrated to a solution of $50 \mathrm{nM}$ peptides. (C) Competitive binding assay with positive controls, ABT-263 and (-)-gossypol $((-) \mathrm{G})$. Compounds were titrated to a solution of preformed 20-mer/Bcl-xL complexes. The concentration was $50 \mathrm{nM}$ for 20-mer and $2 \mu \mathrm{M}$ for Bcl-xL protein. (D-E) HTS was performed with $\sim 50000$ compounds from Prestwick, Microsource, CMLD and Chembridge libraries. The four libraries were divided into two groups and screened separately. Compounds activity (percent of inhibition) of first screen (D) and second screen (E) were shown with $Z^{\prime}$ value indicated on top. Plate median + 3SD was used as a threshold to determine the initial hits. 


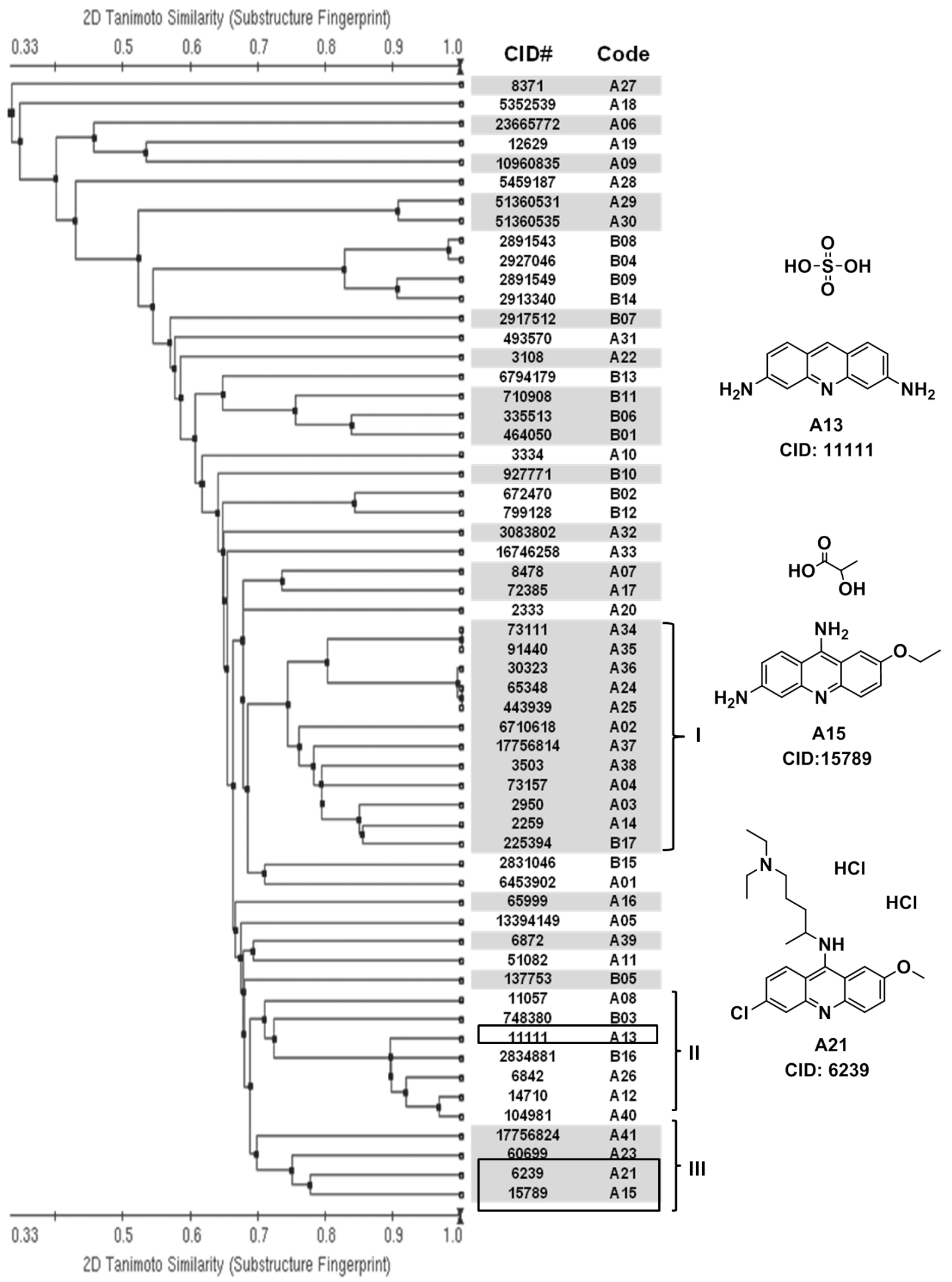

Figure 2: Structural similarity analysis of HTS hits. Left panel: based on the structure (fingerprint) similarity, 58 hits were sorted using a free online clustering tool from PubChem (http://pubchem.ncbi.nlm.nih.gov/). Single-linkage algorithm was used in the clustering, and a Tanimoto distance of 0.3 resulted in 29 different clusters and singletons (shown in white and grey). Compounds are listed by their CID number and code. Chemical structures can be found on the PubChem website, using their CID. Group I, II and III are three major clusters. Right panel: chemical structures of promising candidate compounds from cluster II and III. They contain a common structure of acridine. 
of $10 \mu \mathrm{M}$, while compounds $1,3,6,11,14$ and 15 had almost no binding to $\mathrm{Bcl}-\mathrm{xL}$. The results suggest that the acridine scaffold is essential for compounds to maintain their binding to target, as acridine-lacking group IV has the worst performance in this assay. Moreover, substituent group at the 9 position of acridine ring plays a significant role for the interaction between Bcl-xL and compound, as shown in different performance of compounds 1, 2, 4, 5 and compounds $7,8,9,10$. To be specific, the amino substituent is better than alkyl group at 9 position, and secondary amine is preferred to tertiary amine for a higher affinity. In addition, we found the chloro group at 6 position has no effect on the binding ability, when compared the results of compounds 11 to 14 , as well as 12 to 13 .

We also tested the cytotoxicity of the 17 compounds in human prostate cancer cell lines by MTT assay (Table 1). Compound 7 exhibited the most potent cytotoxicity against all three cell lines with $\mathrm{IC}_{50}$ values less than $0.5 \mu \mathrm{M}$ (Figure 4B). Compound 5 also showed potent cytotoxicity with $\mathrm{IC}_{50}$ in between $0.5 \mu \mathrm{M}$ and 5 $\mu \mathrm{M}$. However, compounds 3, 6, 11, 14 and 15 showed no cytotoxicity in this assay $\left(\mathrm{IC}_{50}>100 \mu \mathrm{M}\right)$. Notably, compounds 5 and 7 displayed higher cytotoxicity in PC-3 and PC-3a cells than in DU145 cells (3-5 fold difference in $\mathrm{IC}_{50}$ value). In summary, cytotoxicity of most compounds correlate with their binding abilities to Bcl-xL protein, which indicate that these compounds may reduce the cell viability via disrupting an oncogenic pathway involving Bcl-2 family proteins.

\section{Compound 7 selectively binds to Bcl-xL and induces autophagy}

From the library of A21 derivatives, compound 7 was identified with potent binding ability to Bcl-xL and cytotoxicity against prostate cancer cells (Figure 4B; Figure $6 \mathrm{~B})$. To gain a further insight into the interactions of compound 7 to $\mathrm{Bcl}-\mathrm{xL} / 2$ protein, we used the SPR assay to test the binding affinity and kinetics. We found
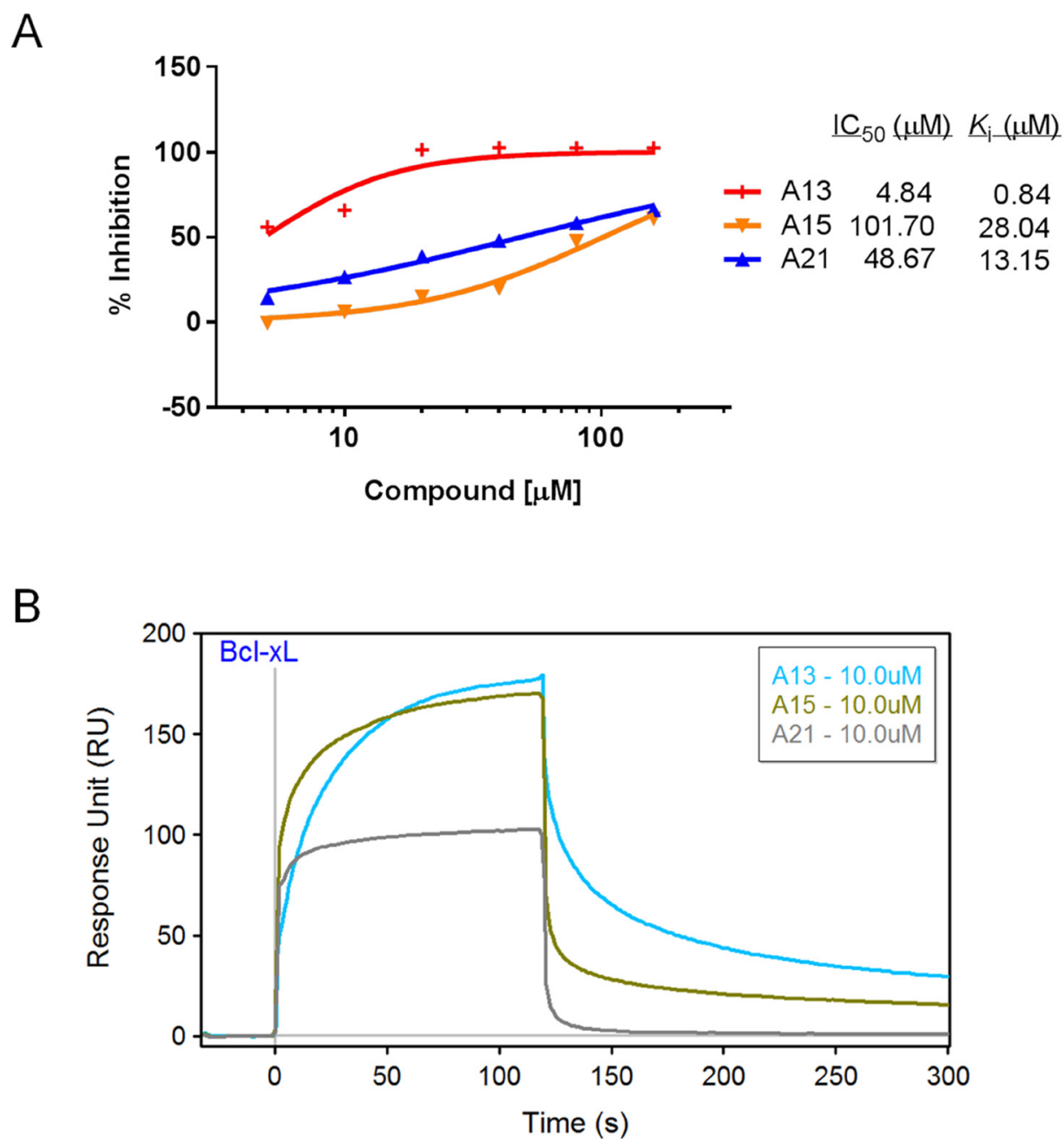

Figure 3: Validation of compounds A13, A15, and A21 binding to Bcl-xL protein. (A) Dose-response curves of acridine compounds disrupting Bcl-xL-20-mer complex in FP assay using $2.5 \mu \mathrm{M}$ Bcl-xL protein and $400 \mathrm{nM}$ fluorescein-labeled Beclin $1 \mathrm{BH} 3$ peptide (20-mer). (B) SPR sensorgram of acridine compounds confirmed their binding abilities to immobilized Bcl-xL protein at the concentration of $10 \mu \mathrm{M}$. Bcl-xL protein was immobilized on the sensor chip with $10000 \mathrm{RU}$. 
Table 1: MTT-based cytotoxicity assay of acridine derivatives

\begin{tabular}{|c|c|c|c|}
\hline \multirow{2}{*}{ Compound } & \multicolumn{3}{|c|}{ Cytotoxicity in different cell lines $\left(\mathrm{IC}_{50}, \mu \mathrm{M}\right)$} \\
\hline & DU145 & PC-3a & PC-3 \\
\hline A13 & $0.81 \pm 0.51$ & $0.68 \pm 0.16$ & $1.08 \pm 0.10$ \\
\hline A15 & $10.47 \pm 1.11$ & $2.33 \pm 0.99$ & $1.61 \pm 0.42$ \\
\hline A21 & $2.31 \pm 0.39$ & $0.80 \pm 0.12$ & $0.77 \pm 0.10$ \\
\hline 1 & $8.15 \pm 0.59$ & $5.81 \pm 1.16$ & $6.04 \pm 0.68$ \\
\hline 2 & $46.98 \pm 7.39$ & $29.20 \pm 11.24$ & $38.73 \pm 5.46$ \\
\hline 3 & $>100$ & $82.66 \pm 7.99$ & NT \\
\hline 4 & $6.33 \pm 0.32$ & $4.37 \pm 0.68$ & $4.43 \pm 0.46$ \\
\hline 5 & $2.78 \pm 0.79$ & $0.74 \pm 0.45$ & $0.79 \pm 0.07$ \\
\hline 6 & $>100$ & $>100$ & $>100$ \\
\hline 7 & $0.27 \pm 0.13$ & $0.10 \pm 0.05$ & $0.11 \pm 0.07$ \\
\hline 8 & $3.68 \pm 0.55$ & $1.64 \pm 0.78$ & $1.42 \pm 0.73$ \\
\hline 9 & $6.24 \pm 1.86$ & $3.51 \pm 1.15$ & $2.93 \pm 1.18$ \\
\hline 10 & $77.66 \pm 24.17$ & $36.09 \pm 8.23$ & $14.13 \pm 0.71$ \\
\hline 11 & $>100$ & $>100$ & $>100$ \\
\hline 12 & $45.44 \pm 8.18$ & $16.42 \pm 2.56$ & $21.56 \pm 2.24$ \\
\hline 13 & $56.97 \pm 14.45$ & $53.86 \pm 3.66$ & $52.39 \pm 10.36$ \\
\hline 14 & $>100$ & $>100$ & $>100$ \\
\hline 15 & $>100$ & $>100$ & $>100$ \\
\hline 16 & $35.99 \pm 13.97$ & $38.69 \pm 20.42$ & $44.96 \pm 20.17$ \\
\hline 17 & $52.96 \pm 14.71$ & $>100$ & $29.49 \pm 28.36$ \\
\hline
\end{tabular}

DU145, PC-3, and PC-3a: Human prostate cancer cell lines. Values are averages of at least two independent experiments. NT: Not tested.

Beclin 1 20-mer peptide and compound 7 have comparable binding affinity to immobilized Bcl-xL protein $\left(K_{\mathrm{D}}=7.3\right.$ $\mu \mathrm{M}$ and $K_{\mathrm{D}}=6.5 \mu \mathrm{M}$, respectively; Figure 7A-7B). We also compared the binding behaviors of compound 7 to the Bcl-xL with that to Bcl-2 protein. It showed that compound 7 has similar dissociated rates to these two proteins, but it associates faster to $\mathrm{Bcl}-\mathrm{xL}$ than to $\mathrm{Bcl}-2$, thus having a lower affinity to $\mathrm{Bcl}-2$ protein $\left(K_{\mathrm{D}}=160.0 \mu \mathrm{M}\right.$; Figure 7C-7D).

We next tested the effects of compound 7 on the autophagy pathway using western blotting. In addition to LC3 conversion, SQSTM1/P62 turnover can also be an important marker for assessing the autophagic flux [34]. Compound 7 triggered the conversion of LC3-I to LC3II and the degradation of P62 in PC-3 and PC-3a cells, indicating its ability to induce autophagy (Figure 8).

\section{DISCUSSION}

Here, we reported the efforts to screen and discover small molecule compounds mimicking the Beclin 1 protein, a BH3-only protein and key inducer of autophagy. In FP-based HTS with 50,316 compounds, we identified 58 initial hit compounds that block the interaction of Beclin
120 -mer to Bcl-xL protein. After structure similarity clustering, three acridine analogues, A13, A15 and A21, were subjected to further analysis. Their binding affinities were reconfirmed in both FP and SPR assay (A13, $K_{\mathrm{i}}=0.84 \mu \mathrm{M}$; A15, $K_{\mathrm{i}}=28.04 \mu \mathrm{M}$; A21, $\left.K_{\mathrm{i}}=13.15 \mu \mathrm{M}\right)$. They showed potent anti-proliferative activity against prostate cancer cells (PC-3, PC-3a and DU145). They activated autophagic flux in PC-3 and PC-3a, determined by LC3 conversion and LC3 puncta assay. These acridine analogues represent a promising starting point for our SAR study. Thus, a small library of 17 acridine analogues has been set up and tested. Compound 7 was identified to bind to Bcl-xL $\left(K_{\mathrm{D}}=6.5 \mu \mathrm{M}\right)$, inhibit cell growth $\left(\mathrm{IC}_{50}\right.$ $<0.5 \mu \mathrm{M}$ against all three cells), and induce autophagy in PC-3 and PC-3a prostate cancer cells. Notably, compound 7 has selectivity for Bcl-xL protein (about 25-fold over Bcl-2). These results validated our design hypothesis that Beclin 1 mimetics, compounds disrupting Bcl-xL-Beclin 1 interaction, could induce autophagy and inhibit cell growth in apoptosis-deficient cancer cells.

Autophagy and apoptosis are two prominent self-destructive processes that control the fate of cells. Generally the cell switches between the two responses in a mutually exclusive manner [36]. However, in some 
cases, autophagy may help to active apoptosis, and excessively autophagy could even lead to autophagic cell death [4]. Early study showed that autophagyassociated cell death can be seen as a backup cell death mechanism when apoptosis fails [8]. Bcl-2 family proteins have been implicated in the regulation of both autophagy and apoptosis [27, 28, 37, 38]. The anti-apoptotic proteins from this family, such as Bcl-2, Bcl-xL or Mcl-1, could inhibit autophagy by binding to Beclin 1 [36]. Some pro-apoptotic BH3 only proteins, such as Bad, Noxa, Puma, could active autophagy by blocking the interaction between Beclin 1 and anti-apoptotic Bcl-2 family members. Moreover the C-terminus of cleaved Beclin 1 (Beclin 1-C) have a apoptosis-promoting function [39]. The Bcl-2/xLBeclin 1 interaction represents a intriguing molecular mechanism between the autophagy and apoptosis. We here focused on the Bcl-xL-Beclin 1 complex, and explored Beclin 1-mimicking agents that disrupt the complex and promote autophagy. However, the effects of our compounds on the apoptotic pathway are still uncertain and warrant further investigation.
Given that deficient autophagy is linked with a wide range of human diseases, many investigations are devoted to identify autophagy inducers [19, 35, 40, 41]. Several available FDA-approved drugs have been repurposed for use in clinical indications, because of their autophagy-inducing activity [10, 42]. However, those drugs possess autophagy-inducing effects as well as other non-autophagy-inducing activities (side effects). The discovery and optimization of novel scaffolds, for maximal specificity and minimal side effect, is a major challenge in this field. The acridine structures we found in this study provided novel templates for further medicinal chemistry optimization. The primary SAR analysis of 17 acridine analogues provided information for further structure-based modifications and lead optimization.

These Beclin 1 mimetics might be promising tools for understanding the roles of Bcl-xL protein, Beclin 1 , and even the multifaceted roles of autophagy in cancer development and drug resistance. In MTT-based cytotoxicity assay, PC-3a and PC-3 cells seem to be more responsive to the compounds than DU145 cells, potentially due to higher levels of Bcl-xL/2. As those compounds
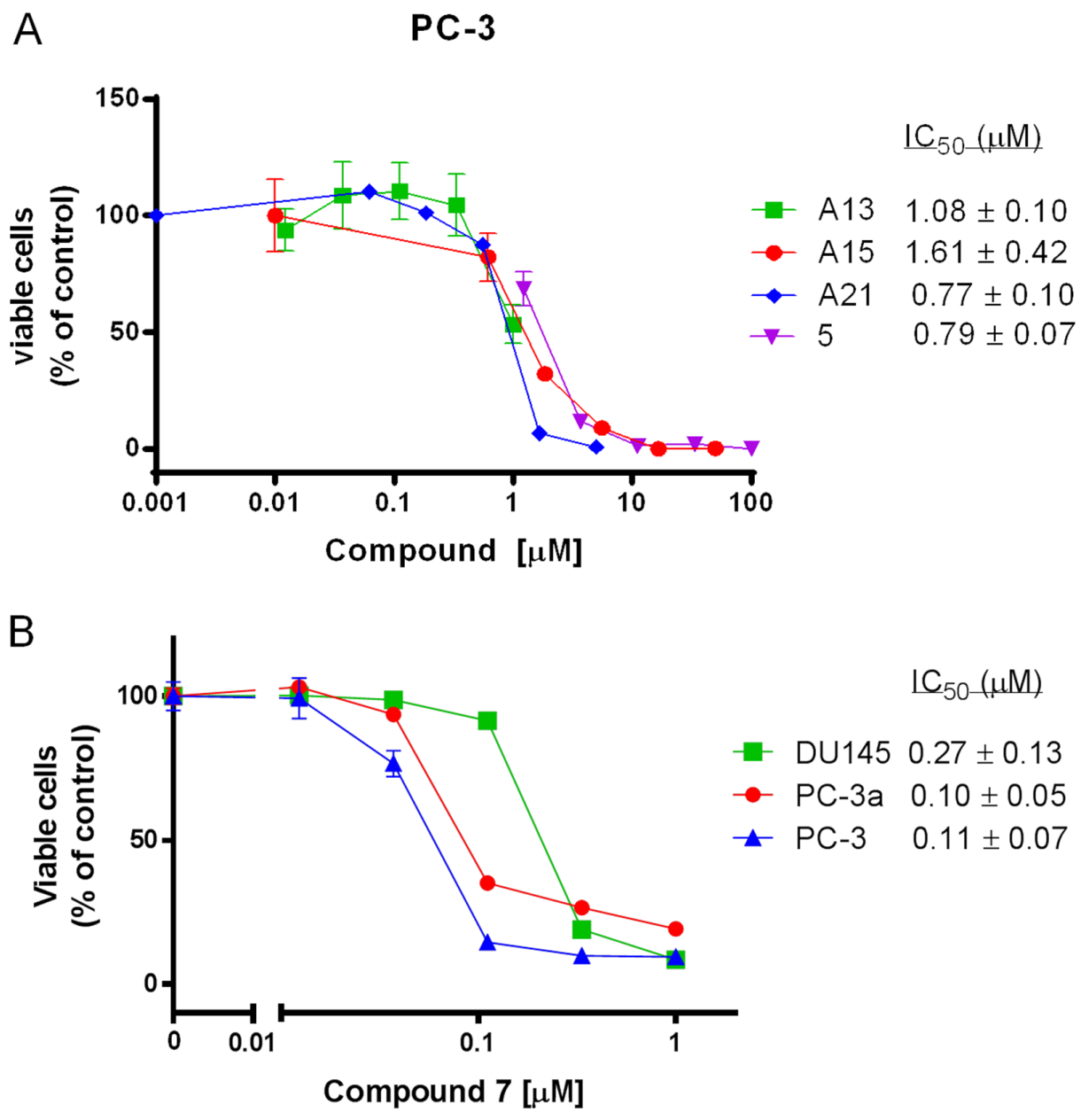

Figure 4: The growth inhibitory effects of several acridine compounds in vitro. (A) Compounds A13, A15, A21, and 5 inhibit PC-3 prostate cancer cell growth in a dose-dependent manner. (B) The cytotoxicity of compound 7 against DU145, PC-3a and PC-3 cancer cell lines. 


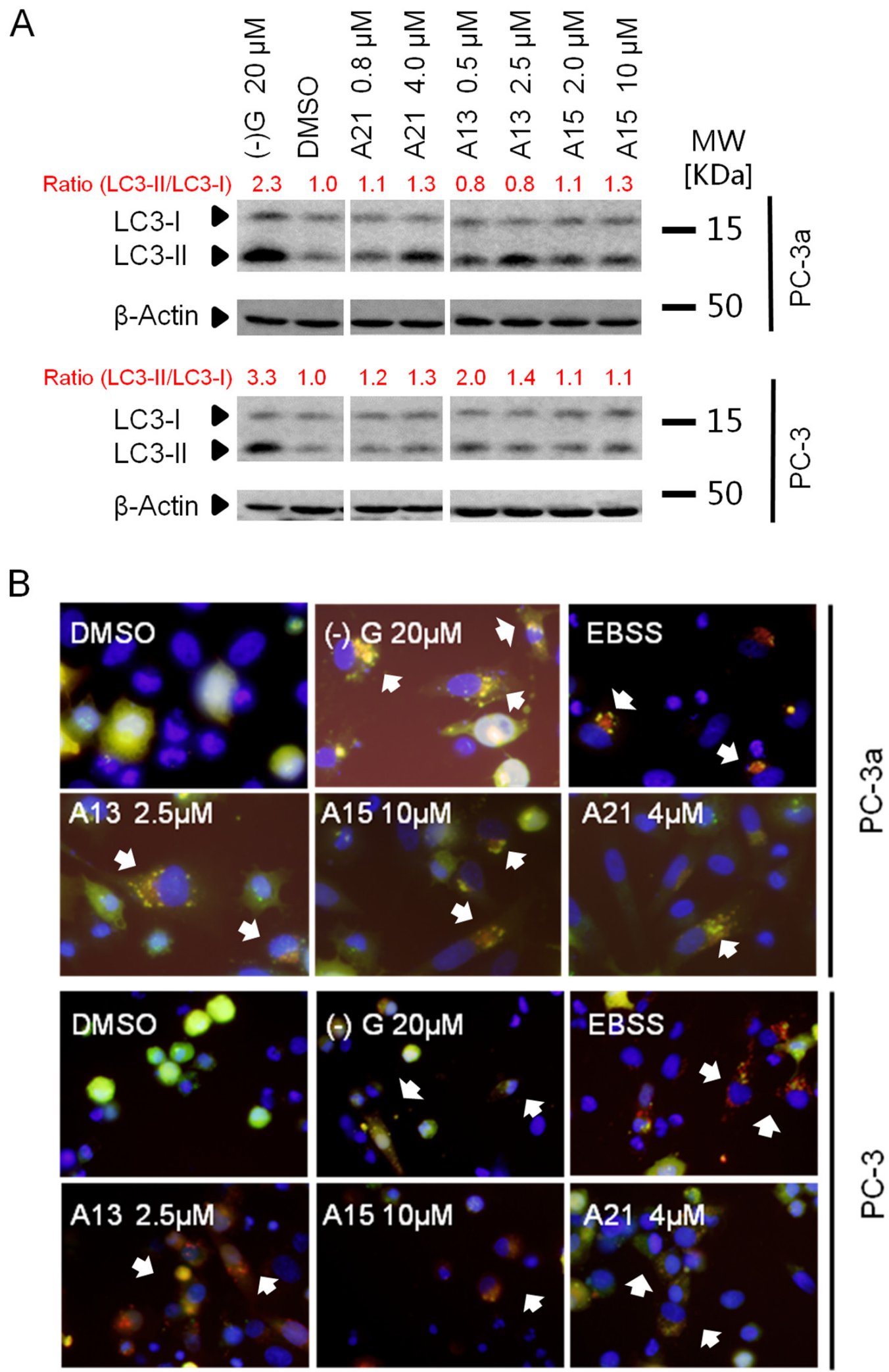

Figure 5: Acridine compounds induce autophagy in prostate cancer cells. (A) LC3-II conversion in western blot analysis indicated the activity of autophagy. Cells were treated with DMSO or compounds for $24 \mathrm{~h}$, and then lysed and processed for western blot analysis of LC3. (-)G and EBSS were used as positive controls. (B) RFP-GFP-LC3 puncta (indicated by white arrows) in cells after treatment suggested the induction of autophagy. Yellow puncta indicate autophagosome (overlay of red and green fluorescence); red puncta indicate autolysosome (due to green fluorescence quenching at the acidic condition). Cells expressing RFP-GFP-LC3 were treated with compounds A13, A15 or A21 at indicated concentration for $24 \mathrm{~h}$. 


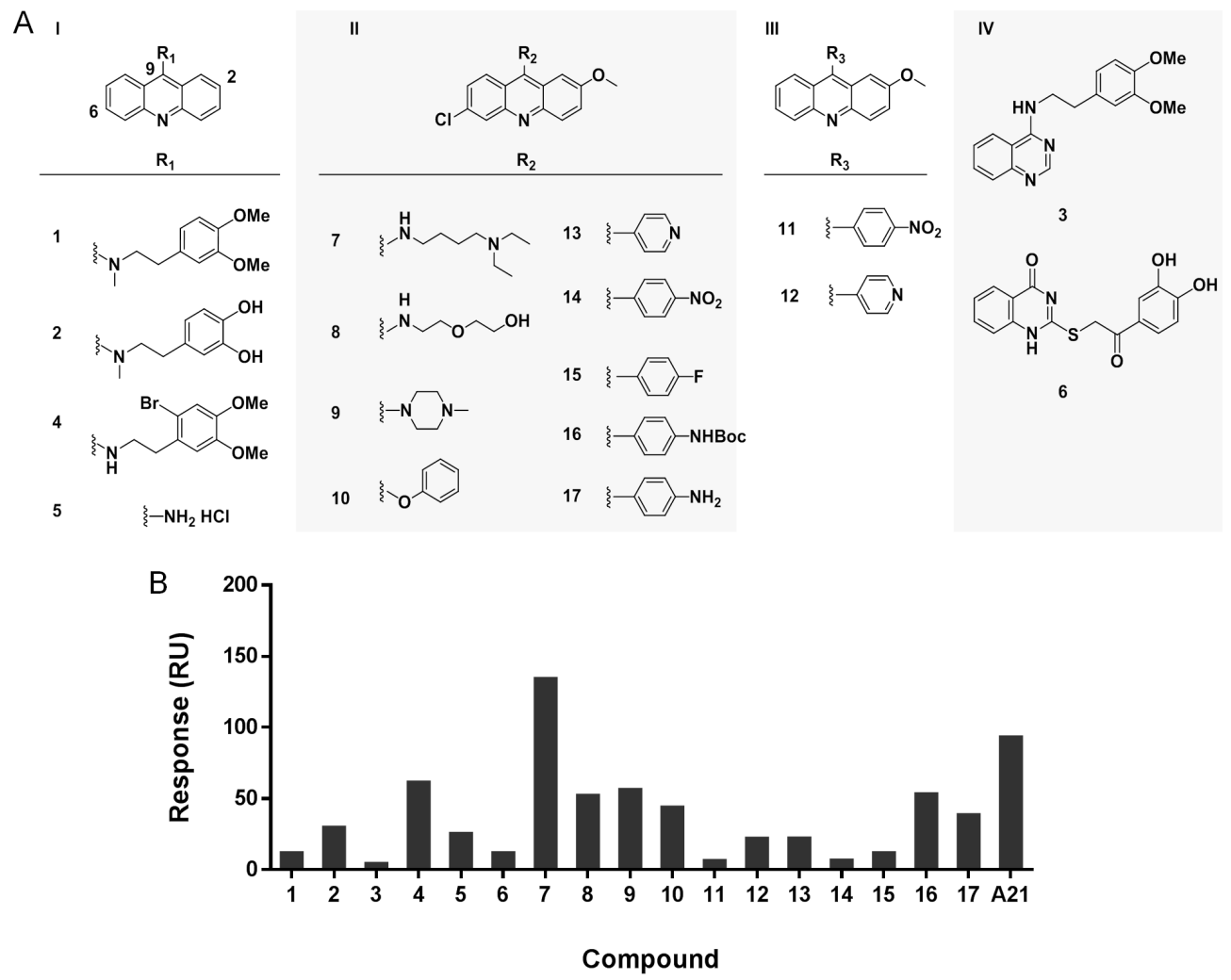

Figure 6: Analysis of structure-activity relationship of A21 derivatives. (A) The chemical structures of acridine derivatives. (B) The maximal binding levels of acridine analogues to Bcl-xL protein at a concentration of $10 \mu \mathrm{M}$ were tested using SPR. The compounds showed different binding ability to Bcl-xL protein.
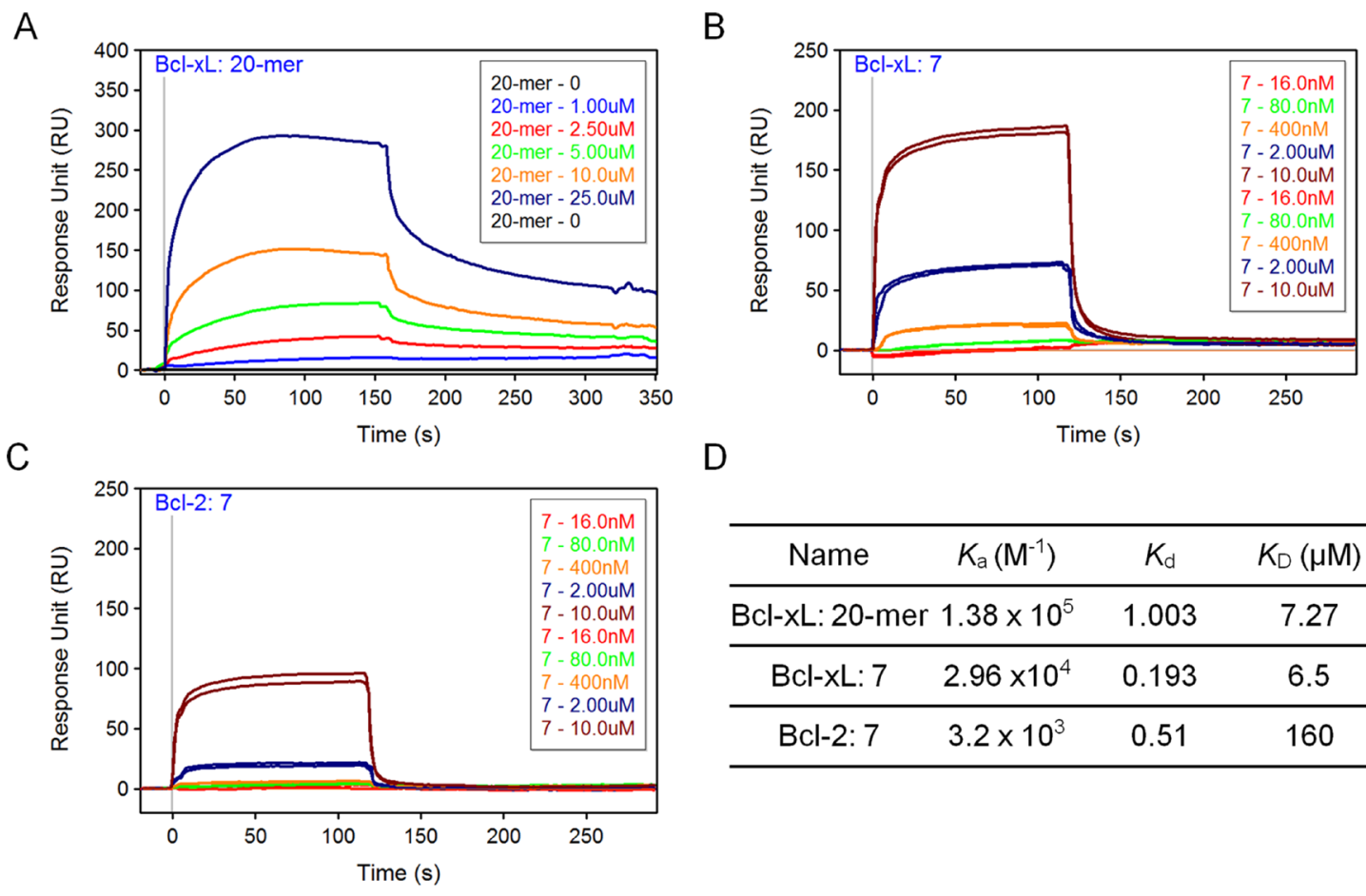

D

\begin{tabular}{cccc}
\hline Name & $K_{\mathrm{a}}\left(\mathrm{M}^{-1}\right)$ & $K_{\mathrm{d}}$ & $K_{\mathrm{D}}(\mu \mathrm{M})$ \\
\hline Bcl-xL: 20-mer & $1.38 \times 10^{5}$ & 1.003 & 7.27 \\
\hline Bcl-xL: 7 & $2.96 \times 10^{4}$ & 0.193 & 6.5 \\
\hline Bcl-2: 7 & $3.2 \times 10^{3}$ & 0.51 & 160 \\
\hline
\end{tabular}

Figure 7: SPR analysis of compound 7. (A, B, C) SPR binding curves, or sensorgrams, for Beclin 20-mer peptide to immobilized Bcl-xL (A), compound 7 to Bcl-xL (B) and compound 7 to Bcl-2 (C). Sensorgrams representing direct binding kinetics for analytes are shown in response unit (RU) as a function of time (second) with increasing concentration $(0.016-10 \mu \mathrm{M}$ for 7 ; $1-25 \mu \mathrm{M}$ for 20 -mer). (D) The association rate $\left(K_{\mathrm{a}}\right)$, dissociation rate $\left(K_{\mathrm{d}}\right)$ and equilibrium dissociation constant $\left(K_{\mathrm{D}}\right)$ were listed. $K_{\mathrm{D}}$ was determined by $K_{\mathrm{d}} / K_{\mathrm{a}}$. 
have been proven to bind to $\mathrm{Bcl}-\mathrm{xL}$ ( 7 has selectivity for Bcl-xL), PC-3a and PC-3 cells are more likely to rely upon $\mathrm{Bcl}-\mathrm{xL}$ for its sustained growth.

Taken together, through our HTS effort and following structural, biochemical, and cellular evaluations, we have identified four potential Beclin 1 mimetics, A13, A15, A21 and 7. They have high binding affinity to Bcl$\mathrm{xL}$, kill prostate cancer cells via disrupting a Bcl-xLrelated oncogenic pathway and activate autophagic flux in prostate cancer cells. These Beclin 1 mimetics represent new templates warranting further medicinal chemistry optimization. Furthermore, these compounds will be good tools for exploring the roles of Bcl-xL in malignant tumor cells and investigating the potential of autophagy to kill cancer cells. Future plan includes design and synthesis of novel acridine-based Beclin 1 mimetics for high potency and selectivity. Moreover, future experiments will focus on exploring target effectiveness, target specificity and mechanism of action studies with the ultimate goal of developing novel small molecule Beclin 1 mimetics modulating autophagy for clinical benefits.

\section{MATERIALS AND METHODS}

\section{Cell culture and reagents}

Human prostate cancer cell lines PC-3 and DU145, were purchased from American Type Culture Collection (ATCC) and used within 50 passages. PC$3 \mathrm{a}$ is a derivative of $\mathrm{PC}-3$ that is resistant to chemo/ radiotherapy, established in our lab and confirmed by genotyping. All cells were maintained in DMEM (Mediatech, Manassas, VA) supplemented with 10\% fetal bovine serum (FBS) (Sigma-Aldrich, St. Louis, MO), 1\% Glutamine (Mediatech, Manassas, VA), 1\% antibiotics (Mediatech, Manassas, VA). Compounds for primary FPbased HTS screening were from Prestwick, Microsource, University of Kansas Center of Excellence in Chemical Methodologies \& Library Development (KU CMLD, Lawrence, KS), and Chembridge libraries. Compounds for MTT and SPR validation experiment were purchased from Microsource (Gaylordsville, CT) and Hit2lead Company (San Diego, CA). Acridine analogues, compound 1-6,

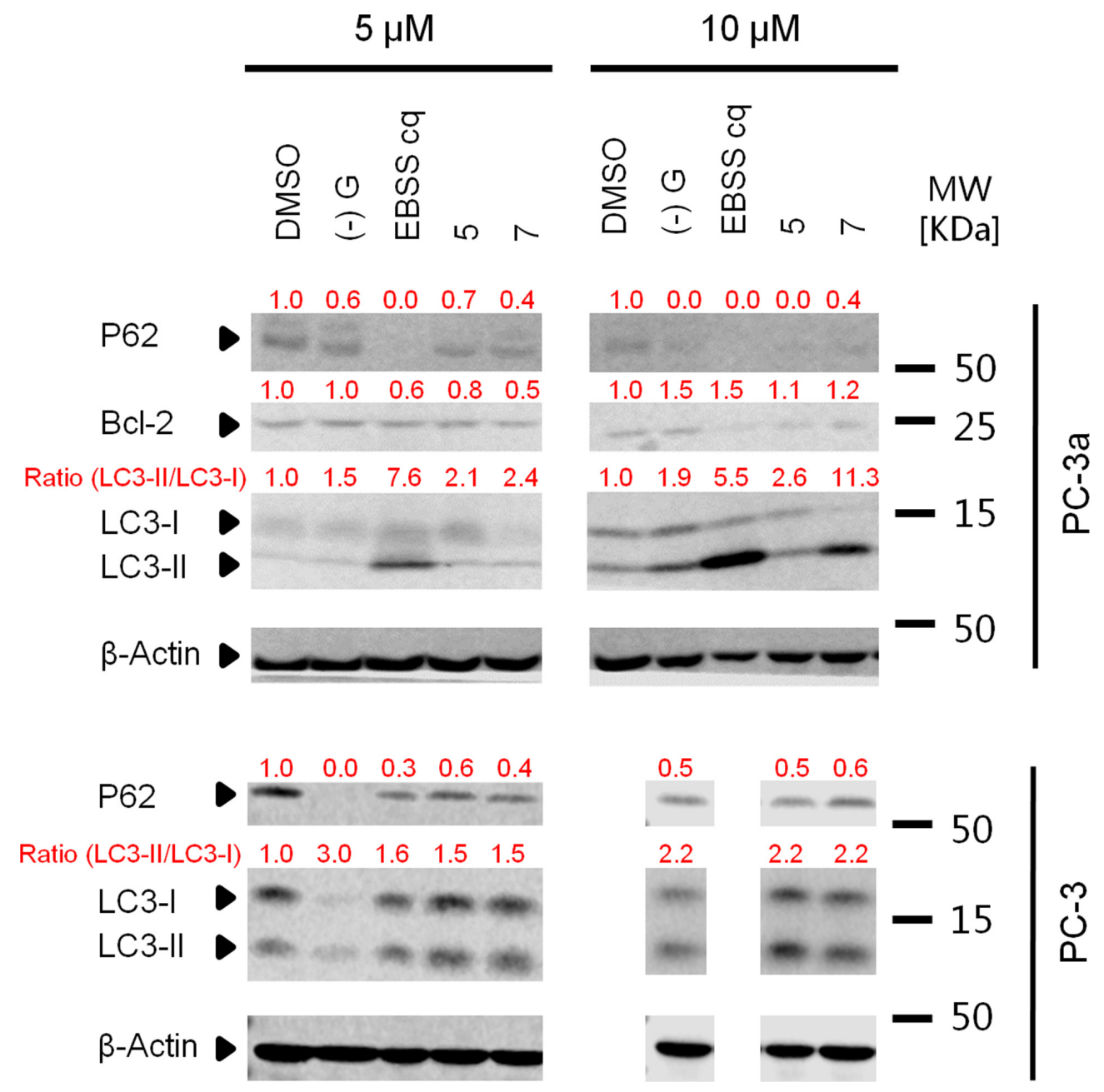

Figure 8: Acridine compounds induce autophagy in PC-3 and PC-3a cancer cells. LC3-II conversion in western blot analysis indicated the activity of autophagy. Cells were treated with DMSO or compounds for $24 \mathrm{~h}$, and then lysed and processed for western blot analysis of LC3. (-)G and EBSS were used as positive controls. 
were from our in-house library (provided by Specialized Chemistry Center, University of Kansas, Lawrence, $\mathrm{KS}$ ); compound 7-17 were synthesized as described in supplementary information. (-)-Gossypol was isolated from racemic gossypol as we previously described $[8,43]$. ABT-263 and DMSO were purchased from Sigma. MTTbased cytotoxicity assay and western blot analysis was carried out according to our previous publications [44]. The primary antibodies used were LC3B (\#2775) (Cell signaling Technology, Danvers, MA) and $\beta$-actin (A5441) (Sigma).

\section{Fluorescence polarization assay}

All $N^{\prime}$-fluorescein-labeled peptides were purchased from Kansas State University (Manhattan, KS). Beclin 1 8-mer, 10-mer, 12-mer, 20-mer and 26-mer peptides were designed in our lab. 16mer Bak (GQVGRQLAIIGDDINR) sequence was from published literature [29, 45]. Bcl$\mathrm{xL}$ protein $(25 \mathrm{kDa},>90 \%$ pure based on SDS-PAGE) was expressed and purified in Protein Product Group, University of Kansas. FP assays were carried out as described in our previous publication $[44,46]$ with some modified. For the assay optimization and determination of equilibrium dissociation constant $(K d)$, purified proteins were serially diluted in binding buffer (20 mM HEPES, $\mathrm{pH} 7.4,0.05 \%$ pluronic F-68), and added to 96-well assay plates (Corning 3915) (Corning, Corning, NY). Then, fluorescein-labeled peptide was added to each well with a final concentration of $50 \mathrm{nM}$ and incubated at room temperature for $30 \mathrm{~min}$. Anisotropy measurements were taken at room temperature using a BioTek Synergy H4 plate reader (Biotek, Winooski, VT) following the protocol recommended by the manufacture. The $K d$ was estimated by nonlinear regression to a one-site binding model using GraphPad Prism 5.0 (GraphPad, San Diego, CA). For competitive binding experiment, compound in serial dilutions ( $1 \mathrm{nM}$ to $100 \mu \mathrm{M}$ ) was added to Bcl-xLBeclin 120 -mer complex in the assay buffer in a 96-well black microplate. The final concentrations of Bcl-xL and 20 -mer were $2 \mu \mathrm{M}$ and $50 \mathrm{nM}$, respectively. Compound solvent DMSO only was used as a negative control in the competition assay. After $2 \mathrm{~h}$ incubation, the plate was read and polarization was calculated.

\section{FP-based high-throughput screening}

To form the Bcl-xL-Beclin 1 complex, Bcl-xL was incubated with Beclin 120 -mer in binding buffer (20 mM HEPES, pH 7.4, 0.05\% Pluronic F-68) for 5 min at $25^{\circ} \mathrm{C}$. Forty microliter aliquots of the mixture were added to the 384-well plates containing the compounds (for a final concentration of $2.5 \mu \mathrm{M}$ Bcl-xL, $400 \mathrm{nM}$ 20-mer, and $40 \mu \mathrm{M}$ compounds in the first screen; and a final concentration of $2.5 \mu \mathrm{M}$ Bcl-xL, $300 \mathrm{nM}$ 20-mer, and $30 \mu \mathrm{M}$ compounds in the second screen) and further incubated at $25^{\circ} \mathrm{C}$ for $2 \mathrm{~h}$. Then the plates were read by Envision (Perkin Elmer, Waltham, MA). The compounds with an inhibition of greater than plate median plus 3 standard deviation were selected as hits. The hits were selected from library stocks and reconfirmed in a concentration response FP assay ( 6 doses ranging from $5 \mu \mathrm{M}$ to $160 \mu \mathrm{M}$ or 8 doses ranging from $0.5 \mu \mathrm{M}$ to $60 \mu \mathrm{M})$. The percent of inhibition was normalized such that the FP value of the protein-peptide complex with DMSO was defined as $0 \%$ inhibition, while the FP value obtained with the same concentration of the free fluorescein-labeled 20 -mer alone was defined as $100 \%$ inhibition.

\section{Surface plasmon resonance assay}

The surface plasmon resonance experiments were performed using a Biacore 3000 (GE Healthcare Pittsburgh, PA) equipped with a research-grade CM5 sensor chip. The ligand (Bcl-xL) was immobilized using amine-coupling chemistry. The surfaces of flow cells on a Biacore sensor chip CM5 were activated for $7 \mathrm{~min}$ with a 1:1 mixture of 0.1 M NHS (N-hydroxysuccinimide) and $0.1 \mathrm{M}$ EDC (3-(N,N-dimethylamino) propyl- $N$ ethylcarbodiimide) at a flow rate of $5 \mu \mathrm{L} / \mathrm{min}$. The ligand (Bcl-xL) at a concentration of $180 \mu \mathrm{g} / \mathrm{mL}$ in $10 \mathrm{mM}$ sodium acetate, $\mathrm{pH} 4.5$, was immobilized at a density of about $10000 \mathrm{RU}$ on flow cell 2; the ligand (SUMOBcl-2, $37.5 \mathrm{kDa},>90 \%$ pure based on SDS-PAGE) at a concentration of $44 \mu \mathrm{g} / \mathrm{ml}$ in $10 \mathrm{mM}$ sodium acetate, $\mathrm{pH}$ 4.5 , was immobilized at a density of $10000 \mathrm{RU}$ on flow cell 3; flow cell 1 was left blank to serve as a reference surface. All the surfaces were blocked with a $7 \mathrm{~min}$ injection of $1 \mathrm{M}$ ethanolamine, $\mathrm{pH}$ 8.0.

For kinetic analysis, a concentration series of analyte were injected over the flow cells at a flow rate of $60 \mu \mathrm{L} / \mathrm{min}$ at $20^{\circ} \mathrm{C}$. The complex was allowed to associate and dissociate for 120 and $180 \mathrm{~s}$, respectively. For binding studies, analyte (or test compound) was injected over the two flow cells in duplicate at indicated concentration at a flow rate of $60 \mu \mathrm{L} / \mathrm{min}$ at $20{ }^{\circ} \mathrm{C}$. The running buffer consisted of $20 \mathrm{mM}$ HEPES, $150 \mathrm{mM} \mathrm{NaCl}, 3 \mathrm{mM}$ EDTA, $1 \mathrm{mM}$ DTT, $0.05 \%$ P20, 5\% DMSO, pH 7.4. The complex was allowed to associate and dissociate for 120 and 180 $\mathrm{s}$, respectively. The buffer samples containing a range of 4-6\% DMSO were injected at the beginning, used for solvent correction. The surfaces were regenerated between binding cycles with a $5 \mathrm{~s}$ injection of $5 \mathrm{mM} \mathrm{NaOH}$ for compounds and $10 \mathrm{mM}$ Glycine $\mathrm{pH} 2.5$ for 20 -mer.

All measurements were taken with flow cell 1 as a reference (i.e. sensorgram depicts "2-1 correction") and corrected for DMSO bulk differences via the calibration curves. To obtain kinetic rate constants $\left(K_{\mathrm{a}}\right.$ and $K_{\mathrm{d}}$ ), corrected response data were fit to a simple $1: 1$ interaction model using local fit (includes correction for mass transport limitations) available within Biaevaluation 3.1 software or Scrubber2 software. The equilibrium dissociation constant $\left(K_{\mathrm{D}}\right)$ was determined by $K_{\mathrm{d}} / K_{\mathrm{a}}$. 


\section{GFP-RFP-LC3 analysis}

PC-3 and PC-3a cells were transfected with ptfLC3 plasmid using Lipofectamine 2000 (Invitrogen Life Technologies, Carlsbad, CA). ptfLC3 was a gift from Tamotsu Yoshimori (Addgene plasmid \# 21074) [47], and is a tandem fluorescent-tagged LC3 with mRFP (mRFP, monomeric Red Fluorescent Protein) and EGFP (EGFP, Enhanced Green Fluorescent Protein). Twenty-four hours after transfection, cells were treated with compounds for $24 \mathrm{~h}$, then fixed in $4 \%$ formaldehyde for $10 \mathrm{~min}$. Cells were then washed three times with PBS, stained with DAPI $(0.5 \mu \mathrm{g} / \mathrm{ml}$ in PBS $)$ for $5 \mathrm{~min}$ and observed under a fluorescence microscope (OLYMPUS IX81, Tokyo, Japan) with X 40 lens.

\section{Abbreviations}

HTS, high-throughput screening; FP, fluorescence polarization; KU CMLD, University of Kansas Center of Excellence in Chemical Methodologies \& Library Development; CID, PubChem Chemical ID; SPR, surface plasmon resonance; RU, response units; SAR, structureactivity relationship; MTT, 3-(4,5dimethylthiazol-2yl)-2,5-diphenyltetrazolium bromide; LC3, light chain 3; PAINS, pan-assay interference compounds; RFP, red fluorescent protein; GFP, green fluorescent protein.

\section{Authors' contributions}

L.X. and J.A. conceived the study, designed and oversaw experiments; S.R. devised synthetic strategies and supervised the chemistry; A.R. performed HTS and analyzed data. P.G. and J.K. supervised biochemical experiment; S.L. performed the western blotting assay; J.Y. and L.L. performed experiments and analyzed data; J.Y., L.L., X.W. and B.S. wrote the manuscript. J.Y. and L.L. contributed equally to this work.

\section{CONFLICTS OF INTEREST}

The authors declare no potential conflicts of interest.

\section{FUNDING}

This study was supported in part by National Institutes of Health grants R01 CA178831 and CA191785 (to L. X., J. A.); NIH COBRE-CCET P30 RR030926 and COBRE-PSF P30 GM110761 Pilot Projects, Kansas Bioscience Authority Rising Star Award, University of Kansas Cancer Center Pilot Grant (to L. X.); National Natural Science Foundation of China (Nos. 21371031), and International S\&T Cooperation Program of China (No. 2015DFG42240).

\section{REFERENCES}

1. Rubinsztein DC, Codogno P, Levine B. Autophagy modulation as a potential therapeutic target for diverse diseases. Nat Rev Drug Discov. 2012; 11:709-30. doi: $10.1038 / \mathrm{nrd} 3802$.

2. Choi AM, Ryter SW, Levine B. Autophagy in human health and disease. N Engl J Med. 2013; 368:651-62. doi: 10.1056/NEJMra1205406.

3. Lorin S, Hamai A, Mehrpour M, Codogno P. Autophagy regulation and its role in cancer. Semin Cancer Biol. 2013; 23:361-79. doi: 10.1016/j.semcancer.2013.06.007.

4. Marino G, Niso-Santano M, Baehrecke EH, Kroemer G. Self-consumption: the interplay of autophagy and apoptosis. Nat Rev Mol Cell Biol. 2014; 15:81-94. doi: 10.1038/ nrm3735.

5. Apel A, Herr I, Schwarz H, Rodemann HP, Mayer A. Blocked autophagy sensitizes resistant carcinoma cells to radiation therapy. Cancer Res. 2008; 68:1485-94. doi: 10.1158/0008-5472.CAN-07-0562.

6. Lindqvist LM, Simon AK, Baehrecke EH. Current questions and possible controversies in autophagy. Cell Death Discov. 2015; 1. doi: 10.1038/cddiscovery.2015.36.

7. Fulda S, Kogel D. Cell death by autophagy: emerging molecular mechanisms and implications for cancer therapy. Oncogene. 2015; 34:5105-13. doi: 10.1038/onc.2014.458.

8. Lian J, Wu X, He F, Karnak D, Tang W, Meng Y, Xiang D, Ji M, Lawrence TS, Xu L. A natural BH3 mimetic induces autophagy in apoptosis-resistant prostate cancer via modulating Bcl-2-Beclin1 interaction at endoplasmic reticulum. Cell Death Differ. 2011; 18:60-71. doi: 10.1038/ cdd.2010.74.

9. Hoyer-Hansen M, Jaattela M. Autophagy: an emerging target for cancer therapy. Autophagy. 2008; 4:574-80. doi: 10.4161/auto.5921.

10. Levine B, Packer M, Codogno P. Development of autophagy inducers in clinical medicine. J Clin Invest. 2015; 125:14-24. doi: 10.1172/JCI73938.

11. Maiuri MC, Tasdemir E, Criollo A, Morselli E, Vicencio JM, Carnuccio R, Kroemer G. Control of autophagy by oncogenes and tumor suppressor genes. Cell Death Differ. 2009; 16:87-93. doi: 10.1038/cdd.2008.131.

12. Lian J, Karnak D, Xu L. The Bcl-2-Beclin 1 interaction in (-)-gossypol-induced autophagy versus apoptosis in prostate cancer cells. Autophagy. 2010; 6:1201-3. doi: 10.1038/ cdd.2010.74.

13. Yang ZJ, Chee CE, Huang S, Sinicrope FA. The role of autophagy in cancer: therapeutic implications. Mol Cancer Ther. 2011; 10:1533-41. doi: 10.1158/1535-7163.MCT-11-0047.

14. Jiang P, Mizushima N. Autophagy and human diseases. Cell Res. 2014; 24:69-79. doi: 10.1038/cr.2013.161.

15. Liang XH, Jackson S, Seaman M, Brown K, Kempkes B, Hibshoosh H, Levine B. Induction of autophagy and 
inhibition of tumorigenesis by beclin 1. Nature. 1999; 402:672-6. doi: 10.1038/45257.

16. Wirawan E, Lippens S, Vanden Berghe T, Romagnoli A, Fimia GM, Piacentini M, Vandenabeele P. Beclin1: a role in membrane dynamics and beyond. Autophagy. 2012; 8:6-17. doi: 10.4161/auto.8.1.16645.

17. Pattingre S, Levine B. Bcl-2 inhibition of autophagy: a new route to cancer? Cancer Res. 2006; 66:2885-8. doi: 10.1158/0008-5472.CAN-05-4412.

18. Levine B, Sinha S, Kroemer G. Bcl-2 family members: dual regulators of apoptosis and autophagy. Autophagy. 2008; 4:600-6. doi: 10.4161/auto.6260.

19. Shoji-Kawata S, Sumpter R, Leveno M, Campbell GR, Zou Z, Kinch L, Wilkins AD, Sun Q, Pallauf K, MacDuff D, Huerta C, Virgin HW, Helms JB, et al. Identification of a candidate therapeutic autophagy-inducing peptide. Nature. 2013; 494:201-6. doi: 10.1038/nature11866.

20. Sun T, Li X, Zhang P, Chen WD, Zhang HL, Li DD, Deng R, Qian XJ, Jiao L, Ji J, Li YT, Wu RY, Yu Y, et al. Acetylation of Beclin 1 inhibits autophagosome maturation and promotes tumour growth. Nat Commun. 2015; 6: 7215. doi: $10.1038 /$ ncomms8215.

21. Sinha S, Levine B. The autophagy effector Beclin 1: a novel BH3-only protein. Oncogene. 2008; 27: S137-S48. doi: 10.1038/onc.2009.51.

22. Oberstein A, Jeffrey PD, Shi Y. Crystal structure of the BclXL-Beclin 1 peptide complex: Beclin 1 is a novel BH3-only protein. J Biol Chem. 2007; 282:13123-32. doi: 10.1074/ jbc.M700492200.

23. Maiuri MC, Criollo A, Tasdemir E, Vicencio JM, Tajeddine N, Hickman JA, Geneste O, Kroemer G. BH3only proteins and $\mathrm{BH} 3$ mimetics induce autophagy by competitively disrupting the interaction between Beclin 1 and Bcl-2/Bcl-X(L). Autophagy. 2007; 3:374-6. doi: 10.4161/auto.4237.

24. Wang J. Beclin 1 bridges autophagy, apoptosis and differentiation. Autophagy. 2008; 4:947-8. doi: 10.4161/ auto.6787.

25. Oltersdorf T, Elmore SW, Shoemaker AR, Armstrong RC, Augeri DJ, Belli BA, Bruncko M, Deckwerth TL, Dinges J, Hajduk PJ, Joseph MK, Kitada S, Korsmeyer SJ, et al. An inhibitor of Bcl-2 family proteins induces regression of solid tumours. Nature. 2005; 435:677-81. doi: 10.1038/ nature 03579 .

26. Maiuri MC, Le Toumelin G, Criollo A, Rain JC, Gautier F, Juin P, Tasdemir E, Pierron G, Troulinaki K, Tavernarakis N, Hickman JA, Geneste O, Kroemer G. Functional and physical interaction between Bcl-X-L and a BH3-like domain in Beclin-1. Embo Journal. 2007; 26:2527-39. doi: 10.1038/sj.emboj.7601689.

27. Chen J, Jin S, Abraham V, Huang X, Liu B, Mitten MJ, Nimmer P, Lin X, Smith M, Shen Y, Shoemaker AR, Tahir SK, Zhang H, et al. The Bcl-2/Bcl-X(L)/Bcl-w inhibitor, navitoclax, enhances the activity of chemotherapeutic agents in vitro and in vivo. Mol Cancer Ther. 2011; 10:2340-9. doi: 10.1158/1535-7163.MCT-11-0415.

28. Cheng P, Ni Z, Dai X, Wang B, Ding W, Smith AR, $\mathrm{Xu} \mathrm{L}, \mathrm{Wu} \mathrm{D}, \mathrm{He} F$, Lian J. The novel BH-3 mimetic apogossypolone induces Beclin-1- and ROS-mediated autophagy in human hepatocellular carcinoma cells. Cell Death \& Disease. 2013; 4. doi: 10.1038/cddis.2013.124.

29. Wang S, Yang D, Xu L. Small molecule antagonists of Bcl-2 family proteins. United States Patent No. US7,432,304, issued on Oct.7, 2008; and US8,163,805, issued on Apr. 24, 2012.

30. Tse C, Shoemaker AR, Adickes J, Anderson MG, Chen J, Jin S, Johnson EF, Marsh KC, Mitten MJ, Nimmer P, Roberts L, Tahir SK, Xiao Y, et al. ABT-263: a potent and orally bioavailable Bcl-2 family inhibitor. Cancer Res. 2008; 68:3421-8. doi: 10.1158/0008-5472.CAN-07-5836.

31. Lessene G, Czabotar PE, Sleebs BE, Zobel K, Lowes KN, Adams JM, Baell JB, Colman PM, Deshayes K, Fairbrother WJ, Flygare JA, Gibbons P, Kersten WJ, et al. Structure-guided design of a selective BCL-X(L) inhibitor. Nat Chem Biol. 2013; 9:390-7. doi: 10.1038/ nchembio.1246.

32. Maggiora G, Vogt M, Stumpfe D, Bajorath J. Molecular similarity in medicinal chemistry. J Med Chem. 2014; 57:3186-204. doi: 10.1021/jm401411z.

33. Baell J, Walters MA. Chemistry: Chemical con artists foil drug discovery. Nature. 2014; 513:481-3. doi: 10.1038/513481a.

34. Klionsky DJ, Abdelmohsen $\mathrm{K}$, Abe A, Abedin MJ, Abeliovich H, Acevedo Arozena A, Adachi H, Adams CM, Adams PD, Adeli K, Adhihetty PJ, Adler SG, Agam G, et al. Guidelines for the use and interpretation of assays for monitoring autophagy (3rd edition). Autophagy. 2016; 12:1-222. doi: 10.1080/15548627.2015.1100356.

35. Baek KH, Park J, Shin I. Autophagy-regulating small molecules and their therapeutic applications. Chemical Society Reviews. 2012; 41:3245-63. doi: Doi 10.1039/ C2cs15328a.

36. Marquez RT, Xu L. Bcl-2:Beclin 1 complex: multiple, mechanisms regulating autophagy/apoptosis toggle switch. Am J Cancer Res. 2012; 2:214-21.

37. Souers AJ, Leverson JD, Boghaert ER, Ackler SL, Catron ND, Chen J, Dayton BD, Ding H, Enschede SH, Fairbrother WJ, Huang DC, Hymowitz SG, Jin S, et al. ABT-199, a potent and selective BCL-2 inhibitor, achieves antitumor activity while sparing platelets. Nat Med. 2013; 19:202-8. doi: 10.1038/nm.3048.

38. Zhou F, Yang Y, Xing D. Bcl-2 and Bcl-xL play important roles in the crosstalk between autophagy and apoptosis. FEBS J. 2011; 278:403-13. doi: 10.1111/j.17424658.2010.07965.x.

39. Wirawan E, Vande Walle L, Kersse K, Cornelis S, Claerhout S, Vanoverberghe I, Roelandt R, De Rycke R, Verspurten J, Declercq W, Agostinis P, Vanden Berghe T, 
Lippens S, et al. Caspase-mediated cleavage of Beclin-1 inactivates Beclin-1-induced autophagy and enhances apoptosis by promoting the release of proapoptotic factors from mitochondria. Cell Death Dis. 2010; 1:e18. doi: 10.1038/cddis.2009.16.

40. Wang FW, Wang SQ, Zhao BX, Miao JY. Discovery of 2'-hydroxychalcones as autophagy inducer in A549 lung cancer cells. Org Biomol Chem. 2014; 12:3062-70. doi: 10.1039/c3ob42429d.

41. Sarkar S, Perlstein EO, Imarisio S, Pineau S, Cordenier A, Maglathlin RL, Webster JA, Lewis TA, O'Kane CJ, Schreiber SL, Rubinsztein DC. Small molecules enhance autophagy and reduce toxicity in Huntington's disease models. Nat Chem Biol. 2007; 3:331-8. doi: 10.1038/ nchembio883.

42. Hidvegi T, Ewing M, Hale P, Dippold C, Beckett C, Kemp C, Maurice N, Mukherjee A, Goldbach C, Watkins S, Michalopoulos G, Perlmutter DH. An autophagy-enhancing drug promotes degradation of mutant alpha1-antitrypsin $\mathrm{Z}$ and reduces hepatic fibrosis. Science. 2010; 329:229-32. doi: 10.1126/science.1190354.

43. Meng Y, Tang WH, Dai Y, Wu XQ, Liu ML, Ji G, Ji M, Pienta K, Lawrence T, Xu L. Natural BH3 mimetic (-)-gossypol chemosensitizes human prostate cancer via Bcl-xL inhibition accompanied by increase of Puma and
Noxa. Molecular Cancer Therapeutics. 2008; 7:2192-202. doi: 10.1158/1535-7163.MCT-08-0333.

44. Lan L, Appelman C, Smith AR, Yu J, Larsen S, Marquez RT, Liu H, Wu X, Gao P, Roy A, Anbanandam A, Gowthaman R, Karanicolas J, et al. Natural product (-)-gossypol inhibits colon cancer cell growth by targeting RNA-binding protein Musashi-1. Mol Oncol. 2015; 9:1406-20. doi: 10.1016/j.molonc.2015.03.014.

45. Petros AM, Medek A, Nettesheim DG, Kim DH, Yoon HS, Swift K, Matayoshi ED, Oltersdorf T, Fesik SW. Solution structure of the antiapoptotic protein bcl-2. Proc Natl Acad Sci USA. 2001; 98:3012-7. doi: 10.1073/pnas.041619798.

46. Wu X, Lan L, Wilson DM, Marquez RT, Tsao WC, Gao P, Roy A, Turner BA, McDonald P, Tunge JA, Rogers SA, Dixon DA, Aube J, et al. Identification and validation of novel small molecule disruptors of HuR-mRNA interaction. ACS Chem Biol. 2015; 10:1476-84. doi: 10.1021/ cb500851u.

47. Kimura S, Noda T, Yoshimori T. Dissection of the autophagosome maturation process by a novel reporter protein, tandem fluorescent-tagged LC3. Autophagy. 2007; 3:452-60. doi: 10.4161/auto.4451. 